\title{
Financial Literacy Studies in South Africa: Current Literature and Research Opportunities
}

\author{
Olawale Fatoki \\ Department of Business Management, Turfloop Campus, University of \\ Limpopo, Limpopo Province, South Africa \\ Email: olawale.fatoki@ul.ac.za \\ Olabanji Oni \\ Department of Business Management, Turfloop Campus, University of \\ Limpopo, Limpopo Province, South Africa \\ Email: olabanji.oni@ul.ac.za
}

Doi:10.5901/mjss.2014.v5n20p409

\section{Abstract}

Financial literacy is of utmost importance for individuals and investors to understand and master financial products and services. Individuals need financial skills to survive in today's volatile economic environment. The objective of the study was to review the current literature on financial literacy in South Africa and suggest research areas that currently lack rigorous investigation. The study thoroughly reviewed the extant literature on financial literacy in South Africa. Fifteen papers, journal articles, theses and dissertations covering the period between 2006 and 2014 were obtained through internet searches. The searches indicated that financial literacy has stimulated many studies in South Africa. The studies focused primarily on individuals, students and small and medium enterprises owners' financial literacy. An analysis of the studies of financial literacy revealed that researchers have used different measuring instruments for the same research objective. This often leads to different conclusions. The areas for further research are suggested.

Keywords: financial literacy, current literature, research opportunities, South Africa.

\section{Introduction}

Lusardi and Mitchell (2013) point out that as financial products and services become widespread, the financial markets have become increasingly accessible to the investor. Many of the financial products are complex and difficult for financially unsophisticated investors to understand. Financial literacy is of utmost importance for investors to understand and master financial products and services. Nieuwenhuyzen (2009) observes that there is the need for individuals to improve their financial knowledge and financial behaviour. Changes in markets and technology necessitate an improvement in financial knowledge and behaviour. The result of financial literacy is that individuals will be better informed, markets will function more effectively and social cohesion and personal wealth will improve. Atkinson and Messy (2011) suggest that the low level of financial literacy of individuals and investors was one of the causes of the recent financial crisis. Lusardi and Mitchell (2011) add that that individuals need financial skills to survive in today's volatile economic environment. Less financially literate individuals are less likely to plan for retirement, less likely to participate in the stock markets and more likely to have more costly debt. Financial literacy impacts on an individual's financial decisions especially in the area of savings, borrowing, retirement planning, or portfolio choice. Scheresberg (2013) agrees that the financial markets have become more complex in the last twenty years. In this new financial landscape, individuals have greater responsibility for their financial security than in the past. This implies that wise and timely saving and investment decisions can be the key to financial comfort. Failure to plan for a financial future can have dire consequences. According to Lusardi et al. (2009), consumers nowadays must confront complicated financial decisions at a young age. Financial mistakes made early in life can be very costly. Young people often carry large amounts of student loans or credit card debt. This may negatively impact on their ability to create and accumulate wealth. Financial literacy impacts on savings by young people. Chowa and Ansong (2010) point the ability of youths to save and accumulate assets becomes very important as this will impact on their ability to accept financial responsibilities and plan for the future. Kotze and Smit (2008) find that household savings have reduced in South Africa. This has been triggered by mounting personal debts. The demand for information on personal finance is increasing. Financial education is the key 
to decreasing financial problems (Ansong and Gyensare 2012).

\section{The Objective of the Study}

The study aims at reviewing the current literature on financial literacy in South Africa. In addition, the study will suggest areas that are lacking rigorous investigation.

\section{Literature Review}

\subsection{Definition of financial literacy}

Huston (2010) points out that there is no universally accepted definition of financial literacy. Authors have proposed several definitions. Huston (2010) describes financial literacy as measuring how well an individual can understand and use personal finance-related information. In addition, financial literacy includes the ability and confidence of an individual to use his/her financial knowledge to make financial decisions. The Organisation for Economic Cooperation and Development (2005) defines financial education leading to financial literacy financial literacy as: "the process by which financial consumers/investors improve their understanding of financial products and concepts and, through information, instruction, and/or objective advice, develop the skills and confidence to become more aware of financial risks and opportunities to make informed choices, to know where to go for help, and to take other effective actions to improve their financial well-being." Vitt et al. (2005) define personal financial literacy as "the ability to read, analyse, manage and write about the personal financial conditions that affect material well-being. It includes the ability to discern financial choices, discuss money and financial issues without (or despite) discomfort, plan for the future, and respond competently to life events that affect every day financial decisions, including events in the general economy". Cude et al. (2006) define personal financial literacy as "the ability to read, analyse, manage and communicate about the personal financial conditions that affect material well-being". ANZ (2008) defines financial literacy as "the ability to make informed judgments and to take effective decisions regarding the use and management of money". ANZ (2011) asserts that financial literacy consists of five separate components. These are keeping track of finances, planning ahead, choosing financial products, staying informed, and financial control.

\subsection{Studies on financial literacy in South Africa}

Internet searches were conducted through the use of a combination of key words such as financial literacy, students, entrepreneurs, journal, thesis and dissertation. Fifteen papers, journal articles, theses and dissertations covering the period between 2006 and 2014 were obtained through the internet searches. The searches indicated that financial literacy has stimulated many studies in South Africa. Most of the studies focused on individuals, students and small and medium enterprises.

\subsubsection{Individuals and students}

Symanowitz (2006) investigated the relationship between financial literacy, economic measures and the delayed gratification of high school leaners in South Africa. The study aimed to quantitatively measure the financial literacy levels of high school students. The study focused on $12^{\text {th }}$ grade students in seven public/private, urban/rural, public/private schools in South Africa. The results indicated a low level of financial literacy for South African $12^{\text {th }}$ grade students. Significant differences were found in the level of financial literacy from different schools, population groups but not gender. The study did not find a significant relationship between financial literacy and ability to delay gratification.

Kotze and Smit (2008) investigated the perceptions of 286 Business Management students with a minimum of three years working and management experience, regarding both their financial literacy and their need and desire for financial education. The participants in the study were selected on the basis of their business background and education. The participants had financial management modules included their studies and it could be assumed that their financial management skills would be above average. The results indicated a positive correlation between adequate financial knowledge and control over personal finances, as well as confidence in managing money and making investment decisions. However, approximately a third of the respondents in the study showed high levels of dissatisfaction with their current level of financial knowledge, perceived control over finances, confidence in money management and making investment decisions. The results suggest that exposure to financial management modules can improve the financial 
literacy of students.

Gouws and Shuttleworth (2009) developed a financial literacy model to measure the comprehensibility of financial information to decision-makers in organisations in South Africa. The study investigated how individual decision-makers in organisations perceive the financial literacy construct. In addition, the study explored how financial literacy is perceived by the various economic sectors and decision-making levels. Nieuwenhuyzen (2009) discovered that there is no single measuring instrument for financial literacy for students in South Africa. The study was designed to test the financial literacy knowledge, financial behaviour and attitude, and measure the ownership of financial products. The measurement instrument allowed for the determination of the consequences of inadequate knowledge. The study developed a 52 item financial literacy questionnaire applicable to the South African context and with a high degree of reliability. Selfadministered questionnaires were administered to first-year students at the South African Military Academy.

Tustin (2010) applied experimental research to investigate the impact of the Bubomi financial literacy flagship programme developed by Absa Group Limited. The objective of the programme is to improve essential financial literacy skills, habits and behaviour of South Africans. The impact of the programme is measured by comparing the level of financial knowledge, confidence, attitude and accountable management practices of statistically representative experimental (people exposed to the Absa training) and control (people not exposed to Absa training) groups residing in village areas surrounding the Giyani town in the Limpopo province. The study found a low level of financial literacy in poor village communities. Shuttleworth (2011) delineated the key concepts within the financial literacy domain and used the Bloom's Taxonomy of educational objectives to determine a possible financial literacy education framework for nonfinancial individuals in organisations

Mishi et al. (2012) investigated the impact of financial literacy programmes on financial inclusiveness of marginalised populace within the Eastern Cape Province. The study found that financial inclusion increase by improvement in literacy levels. Shambare and Rugimbara (2012) investigated financial illiteracy among university students. This is a section of the South African population that could be classified as being educated. A self-administered financial literacy scale was administered to a sample of 214 students from a large South African metropolitan university. The results indicate moderate levels of financial illiteracy. The results suggest that even among the educated, there is a need to reinforce basic financial concepts. Van der Merwe (2012) explored the relationship between economic literacy and allocative efficiency of small-scale producers in South Africa. Personal financial literacy can be regarded to be one of the measures of economic literacy. The results showed that economic literacy does affect the decision-making ability of individuals when it comes to the allocation of production inputs. Cost inefficiencies can be improved by improving the economic literacy of individuals.

Botha (2013) analysed the levels of financial literacy of final year diploma students in different fields of study. The study focused on students studying towards a finance related diploma and students studying towards a non-finance related diploma. The study used a quantitative research approach and self-administered questionnaires were used for data collection in a survey. The study finds that final year diploma students possess a low level of financial literacy. Finance related students performed better than non-finance related students by a small margin, Language and funding style (government or family paid) are the two demographic variables that influence the level of financial literacy. Louw et al. (2013) evaluated the financial literacy needs of third-year students at a South African university. The study focused on evaluating some aspects of the students' socio-economic environment and exposure to financial practices and second, evaluating their personal finance knowledge. The participants in the study were drawn from the faculties Arts, Economic and Management Sciences and Natural Sciences. 424 students completed the questionnaires. The study found that, although the students do not have much exposure with financial practices, they have a good level of knowledge regarding the cluster questions on general financial literacy. This could be attributed to the fact that $60 \%$ of the respondents were students from the Faculty of Economic and Management Sciences. The study also found low to extremely low levels of knowledge exist regarding the clusters of financial planning and investments, banking and taxation and legal matters. The results of this study are consistent with the findings of Kotze and Smit (2008).

Struwig et al. (2013) focused on the generation of information on the levels of awareness, knowledge and understanding of financial literacy and systems at the national level. The study interviewed a total of 2518 people (16 years and older) which were chosen to be representative of 14, 043671 households in South Africa. The study focused on financial literacy measures such as (1) managing money. This included (a) personal involvement in money management. The study found that approximately three-fifths of South Africans aged 16 years and older play some role in managing the household budget. (b) household budgets. The study found that $53 \%$ of the respondents reported the existence of a household budget with $43 \%$ suggesting otherwise and $4 \%$ uncertain or refusing to answer. (c) making ends meet. The study found that almost half the adult population (45\%) reported that they had experienced a shortfall with $54 \%$ indicating that this had not happened to them. (d) attitudes towards spending and saving: $61 \%$ of the respondents 
acknowledged that prior to making a purchase, they always carefully consider whether they can afford it. The study also found that most of the respondents do not plan for emergencies, the most common banking product of which South Africans are aware is a saving account. The most common formal credit and loan products of which South Africans are aware are a lay-bye and a loan from a micro-lender. The investment and savings product that most South Africans are aware of is a pension fund. The next most popular is a stokvel. In addition, most South Africans are aware of life insurance, followed by vehicle or car insurance and medical aid schemes. Furthermore, a majority of South Africans are aware of the burial society as a form of funeral insurance.

\subsubsection{Small and medium enterprises}

Oseifuah (2010) examined the impact of financial literacy on youth entrepreneurship in theVhembe District in South Africa. The study used a structured questionnaire that was developed based on previous studies on financial literacy. The questionnaire focused on the major aspects of financial literacy, including mathematical and computer literacy, financial attitude, financial knowledge and financial behaviour of youth entrepreneurs. The results indicated that the level of financial literacy among youth entrepreneurs is above average. The results of a study by Fatoki (2014) suggest a low level of financial literacy by the owners of new microenterprises. Eresia-Eke and Raath (2013) investigated the relationship between SME owners' financial literacy and business growth. Financial literacy was measured using the keeping of financial records, owners' perceived financial literacy levels and financial training/education. Three elements in Wickham's dynamics of business growth model were used to determine business growth. These are the elements of financial, structural, and strategic growth. Financial growth focused on increase in asset value, capital, turnover and profit. Strategic growth focused on increase in production volume and customer base. Structural growth focused on increase in the number of employees and change in business premises. The study did not find a statistically significant relationship between the SME owners' financial literacy and business growth.

The United States Agency for International Development Southern Africa (2009) focused on the development of strategy options for SME financial literacy. One of the objectives of the study was to define SME financial literacy, The study defined a financially literate SME owner/manager as "someone who knows what are the most suitable financing and financial management options for his/her business at the various growth stages of his/her business; knows where to obtain the most suitable products and services; and interacts with confidence with the suppliers of these products and services. He/she is familiar with the legal and regulatory framework and his/her rights and recourse options". The study further identified SME financial education content requirements leading to financial literacy as information relating to types of funding (including equity finance) and credit products, sources of funding, the requirements from financial institutions to access products and services, other types of financial products, such as savings options for businesses, risk management (business insurance and personal assurance) and the different legal structures for formalising a business.

The Banking Association South Africa (2014) define a financially-literate SME as one which: "(i) has an adequate level of personal entrepreneurial competencies, personal finance skills, and business management skills; has an appropriate level of understanding of functional financial management systems; (ii) has an appropriate level of understanding of SME life-cycle funding and other financial services needs and options and knows where and how to source and negotiate those funding and service requirements; (iii) understands and can manage financial risks or seek relevant advice to manage such risks; (iv) understands legal, regulatory and tax issues as they relate to financial matters; (v) understands the range of legal recourses it can resort to when necessary, and namely, in case of bankruptcy or other situations of financial distress". In addition, the key building block of SME financial literacy include entrepreneurial and basic SME management competencies, understanding of consumer/personal finance, understanding of modern accounting and financial management systems, understanding of financial services options, the types of funding options available to SME and access to finance requirements for SME and the awareness and understanding of financial regulations, legal and tax issues, and related legal recourses a SME can resort to in a situation of financial distress.

\section{Research Opportunities}

An analysis of the studies of financial literacy revealed that researchers have used different measuring instruments for the same research objective. This often leads to different conclusions on the level of personal financial literacy. The development of one unique measuring instrument to measure personal financial literacy that is peculiar to South Africa is an interesting research area. In addition, the measuring instrument can have sections particularly devoted to measuring financial literacy at primary, secondary and tertiary levels. Thus investigating the level of financial literacy not only at secondary and tertiary levels but also at primary level is an exciting research area. This will allow researcher to measure 
financial literacy at both the lowest and the highest levels of education. In addition, research can compare the level of financial literacy for new university students and graduating university students in different faculties. A longitudinal study on financial literacy for students as they move through university levels is another interesting research area. This will enable researchers to discover the impact of university education on personal financial literacy. This kind of study can be extended to Masters of Business Administration (MBA) students. Investigating the levels of financial literacy of local and international students could bring cultural dimensions to financial literacy studies. Differences in the level of financial literacy for business and non-business secondary and university students could bring the area of study dimension to financial literacy. Studies can also focus on measuring the level of financial literacy for different population segments in the rural areas and also rural entrepreneurs. How the level of financial literacy impacts on certain decisions by individuals such as debt level, payment of debt, investment, and credit record is an important research area that needs to be explored. Studies can also explore if there is a gender difference in the level of financial literacy. Developing a model on the determinants of personal/SME owner financial literacy can be an interesting research proposition. Research can also explore how the level of financial literacy impacts on the success/failure, need for and access to external finance by micro, small and medium enterprises. This can be extended to immigrant entrepreneurs. Other interesting research areas include what employers or organisations are doing to improve the financial literacy of employees (including employees that are about to retire), the level of awareness of financial literacy campaign by government and other institutions by youths and people living in the rural areas. This can be extended to whether the present education curriculum at primary, secondary and tertiary level is effective in promoting the personal financial literacy of students. Research can explore how the public-private partnership to promote the levels of financial literacy can be made more effective and the involvement of community-based organisations that are close to the population in improving financial literacy.

\section{Conclusions}

The study reviewed the current literature on financial literacy in South Africa. In addition, the study suggested areas for further research. Fifteen papers, journal articles, theses and dissertations covering the period between 2006 and 2014 were obtained through the internet searches. The searches indicated that financial literacy has stimulated many studies in South Africa. Most of the studies focused on individuals, students and small and medium enterprises. An analysis of the studies of financial literacy revealed that researchers have used different measuring instruments for the same research objective. This often leads to different conclusions on the level of personal financial literacy. There is the need for consistent publication of research findings on the levels of financial literacy by the government or private organisations involved in measuring financial literacy in South Africa. Research areas that can improve the understanding of financial literacy in South Africa are suggested.

\section{Limitations}

It is possible that not all the studies on financial literacy in South Africa have been taken into consideration in this study despite exhaustive internet searches by the researchers.

\section{References}

Ansong, A., \& Gyensare, M.A (2012). Determinants of University Working-Students' Financial Literacy at the University of Cape Coast, Ghana. International Journal of Business \& Management, 7(9): 126-135

ANZ (2008), Survey of Adult Financial Literacy in Australia [Online] Available: http://www.anz.com/Documents/AU/Aboutanz/ AN_5654_Adult_Fin_Lit_Report_08_Web_Report_full.pdf_(November 27, 2013).

ANZ 2011. Adult Financial Literacy in Australia [Online] Available: http://www.financialliteracy.gov.au/media/465153/2011-adult-financialliteracy-full.pdf.pdf (November 27, 2013).

Atkinson, A., \& Messy, ,F. (2011). Assessing financial literacy in 12 countries: an OECD/INFE international pilot exercise. Journal of Pension Economics and Finance, 10(4): 657-665

Banking Association of South Africa (2014), SME Financial Literacy in South Africa [Online] Available: http://www.banking.org.za/index.php/our-industry/small-medium-enterprise/south-african-sme-financial-literacy/_(March 27, 2014)

Botha, Maria, (2013). A comparative analysis of the financial literacy of final year diploma students in different fields of study at the University of Johannesburg [Online] Available: https://ujdigispace.uj.ac.za/handle/10210/8856 (May 20, 2014)

Chowa, G., \& Ansong, D (2010). Youth and Savings in Assets Africa. Children and Youth Services Review, 32 (11): 1591-1596.

Cude, Brenda, Lawrence, Frances, Lyons, Angela, Metzger Kaci, LeJeune, Emily, Marks, Loren, Machtmes, Krisanna (2006), College Students and Financial Literacy: What They Know and What We Need to Learn. [Online] Available:https://www.cgsnet.org/ 
ckfinder/userfiles/files/College_Students_and_Financial_Literacy.pdf (May 9, 2014)

Eresia-Eke, CE., \& Raath, C. (2013). SMME Owners' Financial Literacy and Business Growth. Mediterranean Journal of Social Sciences, 4(13): 397-406

Fatoki, O. (2014). The financial literacy of micro enterprises in South Africa. Journal of Social Science, 40(2):151-158

Huston, S.J (2010). Measuring Financial Literacy. Journal of Consumer Affairs, 44(2): 296-316

Gouws, D.G., \& Shuttleworth, B. (2009). Financial Literacy: An interface between financial information and decision-making in organisations. South African Business Review, 13(2):141-165.

Lusardi, Annamaria, Mitchell, Olivia, Curto, Vilsa (2009), Financial literacy among the young: evidence and implications for consumer policy. [Online] Available: http://www.nber.org/papers/w15352 (May 15, 2014)

Lusardi, A., Mitchell, O (2011). Financial Literacy and Retirement Planning in the United States. Journal of Pension Economics \& Finance, 10(4): 509-525.

Lusardi, Annamaria, Mitchell, Olivia, (2013), The Economic Importance of Financial Literacy Theory and Evidence. [Online] Available: http://arno.uvt.nl/show.cgi?fid=129675 (March 18, 2014).

Kotze, L., \& Smit, AvA (2008). Personal financial literacy and personal debt management: the potential relationship with new venture creation. Southern African Journal of Entrepreneurship \& Small Business Management, 1(1): 35-50.

Louw, J., Fouché, J., \& Oberholzer, M. (2013). Financial Literacy Needs of South African Third-Year University Students. International Business \& Economics Research Journal, 2(4): 439-450.

Oseifuah, E.K. (2010). Financial literacy and youth entrepreneurship in South Africa. African Journal of Economic and Management Studies, 1(2): $164-182$

Scheresberg C (2013). Financial literacy and financial behavior among young adults: evidence and implications. Numeracy, 6(2):1-21

Shambare, R., \& Rugimbana, R. (2012). Financial literacy among the educated: An exploratory study of selected university students in South Africa. Thunderbird International Business Review, 54(4): 581-590.

Shuttleworth, C.C. (2011). A financial literacy education framework for non-financial individuals in organisations. Progressio, 33 (1): $94-$ 115

Mishi, Syden, Vacu, , Portia \& Chipote, Precious (2012), The impact of financial literacy in optimis-ing financial inclusion in rural South Africa: Case study of the Eastern Cape Province. [Online] Available http://www.econrsa.org/system/files/workshops/ papers/2012/mishi-financial-literacy.pdf (March 15, 2014).

Struwig, Jarè, Roberts, Benjamin, \& Gordon, Steven (2013), Financial Literacy in South Africa. Results of a 2012 national survey update. Report prepared by the Human Sciences Research Council on behalf of the Financial Services Board. Pretoria: Financial Services Board.

Organisation for Economic Co-operation and Development (OECD) (2005), Improving financial literacy: Analysis of issues and policies [Online] Available http://titania.sourceoecd.org/vl=4607980/cl=25/nw=1/rpsv/ij/oecdthemes/9998007x/v2005n30/s1/p1l. (February 20, 2014)

Symanowitz, Colette, (2006), The relationship between financial literacy, economic measures and delayed gratification in South African high school learners. [Online] Available: http://upetd.up.ac.za/thesis/available/etd-04012010-124240/unrestricted/dissertation.pdf (May 28, 2014)

Tustin, D.H. (2010). An impact assessment of a prototype financial literacy flagship programme in a rural South African setting. African Journal of Business Management, 4 (9): 1894-1902.

United States Agency for International Development (2009), development of strategy options for SME financial literacy. [Online] Available: http://pdf.usaid.gov/pdf_docs/PNADP093.pdf [Online] Available [March 22, 2014].

Van Der Merwe, Esté, (2012). Economic literacy as a factor affecting allocative efficiency. [Online] Available: http://etd.uovs.ac.za/ETDdb/theses/available/etd-08162012-113236/unrestricted/VanDerMerweE.pdf [May 28, 2014].

Van Nieuwenhuyzen, Bernard, (2009), Financial literacy as core competency of South African military officers: a measurement instrument [Online] Available: http://scholar.sun.ac.za/handle/10019.1/1087 [May 28, 2014].

Vitt, Lois, Reichbach, Gwen, Kent, Jamie, \& Siegenthaler, Jurg (2005), Goodbye to Complacency: Financial Literacy Education in the U.S.: 2000-2005. [Online] Available: research.dwp.gov.uk/asd/asd5/rports2005-2006/rrep239.pdf_[May 19, 2014]. 